\title{
Emotional Intelligence and Job Satisfaction in Greek Banking Sector
}

\author{
Spyros Papathanasiou ${ }^{1 *} \&$ Maria Siati $^{1}$ \\ ${ }^{1}$ School of Social Sciences, Hellenic Open University, Patras, Greece \\ *Corresponding author: Hellenic Open University, School of Social Sciences, Patras, Greece. \\ Tel: 30-210-6900685. E-mail: spyrosp71@gmail.com
}

Received: February 3, 2014 Accepted: March 17, 2014 Published: March 31, 2014

doi:10.5296/rae.v6i1.5050 URL: http://dx.doi.org/10.5296/rae.v6i1.5050

\begin{abstract}
The purpose of this paper is the examination of the issue of emotional intelligence and job satisfaction, concerning a sample of bank employees in the Greek banking sector. Particularly, this paper examines the concept of emotional intelligence and job satisfaction and investigates the application of emotional intelligence based on variables, such as the gender of employees, age, educational level and their previous experience in the Greek banking sector.

In order to satisfy the main objective set above, a conducting quantitative research was designed, based on a questionnaire with closed-ended questions. In combination with the questionnaire' methodology some useful statistical tests and models were used such us Cronbach's Alpha, Kolmogorov-Smirnov's test of normality, Spearman's rho correlation and the simple linear regression model.

The main conclusion of this paper is that gender, age, marital status and job position, representing a portion of the demographic characteristics of the examined sample, affects the levels of emotional intelligence of employees in the banking sector. Additionally, emotional intelligence seems to exert an influence on the everyday life of workers and modulates the levels of professional satisfaction.
\end{abstract}

Keywords: emotional intelligence, job satisfaction, behavioral finance, Greek bank sector 


\section{Introduction}

Emotional intelligence and job satisfaction are two important components in a business environment, both are the object of several studies and provide focus on future and interesting research proposals.

In this paper we attempt to examine the issue of emotional intelligence and job satisfaction, in a sample of employees in the Greek banking sector. It is evident that the banking industry possesses an intense competitiveness and especially nowadays, it is affected by the impact of the financial crisis. Banking services and products offered are homogeneous, resulting in a growing trend of banks to offer differentiated products and services, in an attempt to strengthen their position against competitors in the industry. An important point of reference is the strategies to achieve long-term relationships with customers and emotional intelligence and job satisfaction contribute significantly to that.

The international experience on the approach and solution of this issue is rich through various researches, such as these of Heffernan et al., (2008), Rahim \& Malik, (2010), Kaura, (2011), Orhan and Dincer, (2012), Abi and Jijo, (2012), Jawahar and Samanvitha, (2012), Webb, (2011), Khouly et al., (2010), Locke \& Latham, (2002), Dulewicz, \& Higgs, (1998), Kluemper, (2008), Bhatt, (2004), Mayer et al., (2008), Luet al., (2007), Saari \& Judge, (2004), Arveyet al., (1989), Abraham, (2000), Tapia, (2001), Vasiliou, Eriotis, and Papathanasiou, (2008), Choi et al, (2011). In total, these researches come to the conclusion that emotional intelligence is positively associated with job satisfaction.

In regard to the methodology used, the theoretical background of the research was established through a plethora of secondary sources. Next, the research questions were formed and finally the necessary data for conducting the empirical research was gathered. The result was to delineate the relationships among variables of the research questions.

For this analysis qualitative research was implemented with the use of a questionnaire and conducting interviews at the workplace of the bank employees combined with econometrical analysis. The creation of the questionnaire was based on selected scientific articles and was structured into two main sections, with questions about demographic information and statements concerning the professional satisfaction and emotional intelligence of the bank employees. The data collected from the completed questionnaires was analyzed with the use of the statistical software SPSS.

The main conclusion is that gender, age, marital status, and job position in the bank - forming a part of the demographic characteristics of the sample - affect the levels of emotional intelligence of employees of the banking system. In addition, emotional intelligence seems to exert an influence on the everyday life of employees and modulate the levels of professional satisfaction.

The presented issue of the current paper is an interesting field of study for a number of reasons: Firstly, it contributes to existing knowledge, as notable findings are recorded, compared with the existing empirical studies of researchers on an international basis. Secondly, it offers incentives for future research, due to the comparison with the existing empirical studies of researchers. Thirdly, it can help a bank agency to strengthen its position 
against competitors in the industry, fact that is important nowadays as the banking industry possesses an intense competitiveness. Finally, it contributes to the enrichment of knowledge on the relationship between emotional intelligence and job satisfaction in the banking industry.

This paper contributes to the field of behavioral finance by determining the possible relationship that is developed between emotional intelligence aspects of bank employees and the satisfaction feeling from their work. Research to date has highlighted the importance of emotional intelligence in the workplace, in reference to the application of emotional intelligence based on several demographic variables, such as the gender of employees, age, educational level and their previous work experience.

The structure of this paper is as follows: Section 2 gives a brief discussion of the issues of emotional intelligence and job satisfaction. Then, Section 3 concerns the literature review. Section 4 presents the methodological issues, while Section 5 describes the sample data and presents the empirical results. Finally, Section 6 draws the main conclusions.

\section{Emotional Intelligence and Job Satisfaction}

Salovey and Mayer (1990) were the first who defined emotional intelligence, as "The ability to monitor one's own and others' feelings, to discriminate among them, and to use this information to guide one's thinking and action". Later, Mayer and Salovey (1997) developed the four-branch model or ability model of emotional intelligence, analyzing the perception of emotion, the ability reason using emotions), the ability to understand emotions and the ability to manage emotions. During the popularization of emotional intelligence, Goleman (1998) defined emotional intelligence as "Knowing ones' emotions", "Managing emotions", "Motivating oneself", "Recognizing emotions in others" and "Handling relationships". Bar-On (1997), defined emotional intelligence as the "skills which influence one's ability to succeed", in his book Bar-On Emotional Quotient Inventory: A measure of emotional intelligence (1997).

Job satisfaction was firstly defined by Locke (1976), as "a pleasurable or positive emotional state resulting from the appraisal of one's job or job experiences". Job satisfaction is highly related to employees' behavior (Edwards \& Fisher, 2004; Kraut, 1996) and is connected to the motives that can be provided in the business environment.

\section{Literature Review}

A significant number of studies have examined the possible relationship that is developed between the aspects of emotional intelligence of bank employees and the satisfaction they feel from their work. The investigation of Heffernan et al. (2008) highlighted the impact of emotional intelligence and confidence on the financial performance of executives in the banking sector.

Malik \& Rahim (2010) explored the impact of demographic factors on the level of emotional intelligence and hence the performance of employees on the job. The study of Kaura (2011) 
showed that there is a strong correlation between emotional intelligence and the dimensions of service quality.

The study of Orhan \& Dincer (2012) focused on the relationship between emotional intelligence and job satisfaction. In addition the study of Abi \& Jijo (2012) showed how the work experience and the marital status affect the emotional intelligence and satisfaction at work. The results showed very high positive correlation between emotional intelligence and job satisfaction. The research of Jawahar \& Samanvitha (2012) in India has shown that there is a strong correlation between emotional intelligence and at the level of job satisfaction and performance. Besides Webb (2011) examined the levels of emotional intelligence of employees in relation to their satisfaction from their work and dedication in leading vision, concluding that there is a remarkable importance of high satisfaction and commitment among employees.

Khouly et al. (2010) came to the result that individuals who have high emotional intelligence are more satisfied with their jobs than it happens with employees who have low emotional intelligence. Also, gender and job satisfaction do not correlate significantly, while emotional intelligence and job satisfaction are highly correlated and emotional intelligence and gender interact to affect job satisfaction.

Choi et al (2011), through their research among 288 workers in South Korea, concluded that emotional intelligence is positively associated with the behaviors of workers at the workplace (job satisfaction and commitment to the company). Viewing the above, a further investigation should be proposed concerning the generalization of the research results, both in the public and private sector at an over time basis.

\section{Methodological Issues}

\subsection{Research questions}

The purpose of this paper is the identification of the possible relationship that is being developed between the aspects of emotional intelligence of employees of the Greek banking system and the satisfaction they feel from their work. This research proposes as the main research question the following: "What is the relationship between the aspects of emotional intelligence of bank employees and the satisfaction they feel from their work? It also makes six secondary research hypotheses:

$1^{\text {st: }}$ Emotional intelligence is correlated with the gender of employees of the banking sector.

$2^{\text {nd. }}$ : The age of bank employees affects their emotional intelligence.

$3^{\text {rd }}$ : The marital status of employees of the banking sector affects the levels of emotional intelligence.

$4^{\text {th: }}$ There is impact of the educational level of employees of the banking sector at the level of emotional intelligence.

$5^{\text {th: }}$ The job position of bank workers affects the levels of emotional intelligence.

$6^{\text {th: }}$ The levels of emotional intelligence are increasing as the job experience of bank officials 
is growing.

\subsection{Methodology}

The selection of an appropriate method for an empirical research is heavily important for the researcher. There are two search methods, qualitative and quantitative. In this paper the qualitative method is applied (Kyriazopoulos \& Samada, 2011).

The majority of surveys that have been conducted in the past on the present topic make use of quantitative research. Predefined questionnaires with closed-type questions are used to collect data and conduct statistical conclusions both for emotional intelligence, as well as for professional satisfaction. Therefore, the present research was qualitative, using the methodology of the questionnaire, with a structured, personal interview. The duration of its completion took 10 to 15 minutes. The questions of the questionnaire relied on a study that was conducted to bank employees for their professional satisfaction, concerning the survey by Rajesh J Bhatt (2004). The creation of the section B2 of the questionnaire was based on the questionnaire of 33-elements of Schutte et al. (1998).

The methodology of questionnaire was conducted in the period from 02/26/13 - 03/12/13. The venue of the personal interview was the workspace of the employees, i.e. branches of Greek banks included in the survey (National Bank of Greece, Commercial Bank, Alpha Bank, Piraeus Bank, Bank of Cyprus, Agriculture Bank, General Bank of Greece, Marfin Bank, Eurobank, FBB and others). The areas of research were the prefectures of Achaia, Preveza, Athens and Chania. The final sample size was 129, reduced from 160 that had been laid initially, due to the limitations of the research. The selection was made with simple random sampling.

In combination with the questionnaire' methodologysome useful statistical tests and models were used such us Cronbach's Alpha, Kolmogorov-Smirnov's test of normality, Spearman's rho correlation and the simple linear regression model.

Cronbach's Alpha is used as a measure of the internal consistency of a test or scale and takes values between 0 and 1 . More specifically, internal consistency defines the extent to which all the items in a questionnaire measure the same concept and check whether the inter-relatedness of the items exists (Tavakol, Dennick, 2011). As Razal and Wah (2011) state, it is crucial the test of normality be applied to a statistical analysis since a semantic assumption of many statistical procedures such as t-tests and linear regression analysis. Once the normality of data is rejected, there are many possibilities of not having reliable results. One of the most popular tests applied in many statistical studies is Kolmogorov-Smirnov's test of normality.

Spearman's rho correlation is a nonparametric measure of statistical dependence between two variables. This measure takes values between -1 and 1 , showing the extent of how correlated the variables under study are (Caruso, Cliff, 1997).

To predict the relationship between two factors, the implementation of the simple linear regression model is suggested. The factor that is being predicted is called the dependent variable and the variable that is used to predict the dependent variable is called the independent variable. The simple linear regression model is represented like $\mathrm{Y}=\mathrm{a}+\mathrm{b} * \mathrm{X}+\mathrm{e}$, 
where $\mathrm{Y}$ is the dependent and $\mathrm{X}$ the independent variable respectively. The term e represents the error term in the model (Kenney, Keeping, 1962).

\section{Data and Empirical Results}

\subsection{Data}

Table 1 shows in detail the distribution of sample questionnaires.

Table 1. Distribution of Questionnaires

\begin{tabular}{ccc}
\hline Given Questionnaires & Valid & Void \\
\hline $\mathrm{N}=160$ & 124 & 36 \\
& $(77.5 \%)$ & $(22.5 \%)$ \\
\hline
\end{tabular}

Source: Results of the Survey Questionnaire

In the sample there is a minimal difference in the number of men and women of the bank employees of Greece. In regard to the age distribution of the sample, the largest percentage of employees of the banking system (58.1\%) is individuals aged 30-40 years. Then, analyzing the marital status of the sample, it was observed that a large percentage of employees were married (78 individuals), as opposed to the fact that nearly half of the employees were unmarried (42 individuals).

Concerning the educational level of employees of the banking system in Greece, it was observed that the majority of the bank employees were quite highly educated. Despite the high level of education of the sample, it was noted that 76 people out of 124 hold the position the bank clerk in the banking industry, 40 people are department managers and only 8 the position of the Director.

Concluding the presentation of the demographics of the sample, the largest percentage of employees work less than ten years in the banking sector, thus making $45.2 \%$ of the total. On the contrary, $11.0 \%$ of the sample has more than 20 years of work experience.

\subsection{Empirical Analysis of the Questionnaire (Cronbach's Alpha ratio)}

The purpose of the research is the study of the correlation between emotional intelligence of bank officials and their professional satisfaction. In the second part of the questionnaire, of 10 questions are used for measuring professional satisfaction and also another of 33 questions that make up the questionnaire SREIT for analyzing emotional intelligence.

Table 2 shows both the average and standard deviation of each reply to the questionnaire obtained by sample answers. In addition, reference is made to the maximum and minimum value of each reply recorded by employees. 


\section{Al Macrothink}

Table 2. Statistical analysis of the questionnaire's questions

\section{SECTION A}

\begin{tabular}{|c|c|c|c|c|c|}
\hline & Job Satisfaction & Average & $\begin{array}{l}\text { Standard } \\
\text { Deviation }\end{array}$ & Maximum & Minimum \\
\hline 1 & I feel pretty accomplished with the job I have now. & 3.48 & 0.82 & 5 & 1 \\
\hline 2 & $\begin{array}{l}\text { I'm satisfied with the way my supervisor supervises my } \\
\text { professional career. }\end{array}$ & 3.44 & 0.97 & 5 & 1 \\
\hline 3 & My daily work is recognized. & 3.61 & 0.85 & 5 & 1 \\
\hline 4 & $\begin{array}{l}\text { I'm satisfied with my working conditions, such as the } \\
\text { building I work at. }\end{array}$ & 3.81 & 0.88 & 5 & 1 \\
\hline 5 & $\begin{array}{l}\text { I'm satisfied with my reputation in the wider social level, } \\
\text { which is obtained due to my professional position. }\end{array}$ & 3.71 & 0.80 & 5 & 1 \\
\hline 6 & I'm pleased with my annual financial earnings. & 3.27 & 1.00 & 5 & 1 \\
\hline 7 & $\begin{array}{l}\text { Opportunities are given for personal professional } \\
\text { development. }\end{array}$ & 3.27 & 0.97 & 5 & 1 \\
\hline 8 & $\begin{array}{l}\text { I'm satisfied with the personal relationships I have } \\
\text { developed with other employees in my workplace. }\end{array}$ & 4.14 & 0.60 & 5 & 3 \\
\hline 9 & $\begin{array}{l}\text { I would suggest to a friend of mine a future professional } \\
\text { collaboration in my workspace. }\end{array}$ & 3.60 & 0.80 & 5 & 1 \\
\hline 10 & $\begin{array}{l}\text { I feel secure in my job. } \\
\text { SECTION B' }\end{array}$ & 3.28 & 0.98 & 5 & 1 \\
\hline & Emotional Intelligence & & & & \\
\hline 11 & $\begin{array}{l}\text { I know when to talk about my personal problems to } \\
\text { others. }\end{array}$ & 3.97 & 0.84 & 5 & 1 \\
\hline 12 & $\begin{array}{l}\text { When I face problems, I recall similar situations that I } \\
\text { have encountered in the past and I overcome them. }\end{array}$ & 3.94 & 0.65 & 5 & 2 \\
\hline 13 & $\begin{array}{l}\text { I expect that I will do the best for things I am } \\
\text { responsible for }\end{array}$ & 4.28 & 0.55 & 5 & 2 \\
\hline 14 & Other people trust me easily. & 3.85 & 0.65 & 5 & 2 \\
\hline 15 & $\begin{array}{l}\text { I find it difficult to understand others' non-verbal } \\
\text { messages. }\end{array}$ & 2.50 & 0.93 & 5 & 1 \\
\hline 16 & $\begin{array}{l}\text { Some events in my life have led me to re-evaluate what } \\
\text { is important and what is not. }\end{array}$ & 4.19 & 0.74 & 5 & 1 \\
\hline 17 & When my mood changes, I see new possibilities. & 3.76 & 0.79 & 5 & 2 \\
\hline 18 & $\begin{array}{l}\text { Emotions are one of the things that make my life } \\
\text { worthwhile. }\end{array}$ & 4.17 & 0.87 & 5 & 1 \\
\hline
\end{tabular}


27 When I'm cheerful, it is easy to solve various problems.

I understand the feelings of others through their facial expressions.

29 I know why my emotions change.

30 When I'm cheerful, I think of new ideas.

31 I have control over my emotions.

I acknowledge my feelings easily, when I experience them.

33 I incite myself to imagining the positive outcome of my duties.

34 I congratulate others when they do something well.

35 I'm aware of non-verbal messages sent by others.

I have the same emotions with people around me

36 when they describe to me a positive or negative 3.63

0.75 experience of theirs.

When I experience a change of feelings, I come up with new ideas.

38 When I confronted with a challenge, I abandon my effort due to possible failure.

39 I know the feelings of others when I look at them.

40 I animate those around me, when they are in a negative situation.

41 I think positively in order to solve my problems.

42 I understand the feelings of others by the tone of their voice. do.

Source: Results of the Survey Questionnaire

The consistency of the above is verified by the contribution of the reliability analysis based on the Cronbach's Alpha. As shown in table 3 below, the ratio is quite high for both teams, so we can assume that the questions represent and define both job satisfaction and emotional 
intelligence as measured variables.

Table 3. Reliability analysis of professional satisfaction and emotional intelligence

\begin{tabular}{lll}
\hline & Cronbach's Alpha & Number of Items \\
\hline Job Satisfaction & 0.845 & 10 \\
Emotional Intelligence & 0.896 & 33 \\
\hline
\end{tabular}

Source: Results of the Survey Questionnaire

For the sample of 124 employees, the average professional satisfaction equals 35.62 with standard deviation of 5.66. The range of professional satisfaction varies from 21 to 49. The average emotional intelligence equals to 120.65 with standard deviation of 12.35 . The range of emotional intelligence ranges from 63 to 155. The above are shown in table 4.

Table 4. Statistical analysis of the sample

\begin{tabular}{lll}
\hline $\mathrm{N}=124$ & Job Satisfaction & Emotional Intelligence \\
\hline Average & 35.62 & 120.65 \\
Standard Deviation & 5.66 & 12.35 \\
Maximum Value & 49 & 155 \\
Minimum Value & 21 & 63 \\
Values' Range & 28 & 92 \\
\hline
\end{tabular}

Source: Results of the Survey Questionnaire

\subsection{Kolmogorov-Smirnov test for normality}

The statistical analysis that was applied on the study of research hypotheses concerns the correlation analysis of the corresponding parameters for both the main research question, and the secondary research hypotheses. Primarily, for the use of the correlation analysis it is important to study the normality of the parameters in order to properly select the correlation coefficient for this study (Schutte et al., 1998; Henry, Hope, 2013; Adeyemo, n.d).

The statistical test for studying normality of data is the Kolmogorov-Smirnov test for normality. We define as a null hypothesis the normality of variables and as alternative hypothesis the non-normality. Table 5 lists the tests of normality of demographics, emotional intelligence, and professional satisfaction.

Table 5. Testing the normality of the parameters

\begin{tabular}{llll}
\hline & \multicolumn{3}{l}{ Kolmogorov-Smirnov } \\
& Statistic & df & p-value \\
\hline Gender & .349 & 124 & .000 \\
Age & .121 & 124 & .000 \\
Marital Status & .390 & 124 & .000 \\
Education & .232 & 124 & .000 \\
Job position in the Bank & .381 & 124 & .000 \\
Years of experience in the Bank & .131 & 124 & .000 \\
Job Satisfaction & .088 & 124 & .019 \\
Emotional Intelligence & .123 & 124 & .000 \\
\hline
\end{tabular}


Source: Results of the Survey Questionnaire

Observing the above table, all variables of this statistical analysis do not seem to follow the normal distribution, as the corresponding values of variables' $p$-value is less than $90 \%$ confidence level that we have defined in this study (Schutte et al., 1998). The null hypothesis is not accepted considering the fact that the variables are not normally distributed.

\subsection{Spearman's rank correlation coefficient}

Based on the results derived from testing normality though Kolmogorov-Smirnov test, it was decided to use the Spearman's correlation coefficient (rho) for making the correlation analysis and conducting the statistical findings. The Spearman coefficient is recommended for non-normal data (Chok, 2010).

For the study of the main research hypothesis, the correlation analysis between the variables of emotional intelligence and professional satisfaction were used. The Spearman correlation coefficiently calculated by SPSS equals 0.327 . The corresponding p-value of statistical test is 0.000 . As the confidence level of this study is $90 \%$, p-value is less than $0.10(100 \%-90 \%)$ and so we accept the null hypothesis of the correlation of these two variables. Therefore, it is considered that emotional intelligence is positively correlated with job satisfaction at $31.6 \%$.

The next stage of the statistical analysis is the study of the secondary research hypotheses. The following table 6 presents the overall results obtained from the statistical analysis of the correlation coefficient in accordance with the theory of Spearman.

Table 6. Correlation Analysis in accordance with the theory of Spearman

\begin{tabular}{llll}
\hline & \multicolumn{3}{c}{ Emotional Intelligence } \\
\cline { 2 - 4 } & Spearman's rho & $\mathrm{N}$ & $\mathrm{p}$-value \\
\hline $\begin{array}{l}\text { Main Research Hypothesis } \\
\text { Job Satisfaction }\end{array}$ & .316 & 124 & .000 \\
Secondary Research Hypotheses & & & \\
Gender & .248 & 124 & .005 \\
Age & .168 & 124 & .062 \\
Marital Status & -.293 & 124 & .001 \\
Education & -.048 & 124 & .593 \\
Job position in the Bank & .148 & 124 & .102 \\
Years of experience in the Bank & .142 & 124 & .116 \\
\hline
\end{tabular}

Source: Results of the Survey Questionnaire

As about the secondary research hypotheses, we have the following:

$\left(1^{\text {st }}\right)$. The Spearman coefficient is calculated 0.248 with p-value 0.005 . At $90 \%$ confidence level, there seems to be a positive correlation between gender and emotional intelligence.

$\left(2^{\text {nd }}\right)$. The Spearman coefficient equals 0.168 with corresponding value p-value 0.062 and therefore, the age of employees in the banking sector is positively correlated with emotional intelligence. 
$\left(3^{\text {rd }}\right)$. The Spearman coefficient equals- 0.293 and the corresponding p-value equals 0.001 . So, at $90 \%$ confidence level, the marital status of Bank officials seems to be negatively correlated with emotional intelligence.

$\left(4^{\text {th }}\right)$. The Spearman coefficient was calculated-0.048. The $p$-value value equals 0.593 , fact that implies that there is no correlation between the level of education among employees of banking system and emotional intelligence in a $90 \%$ confidence level.

$\left(5^{\text {th }}\right)$. The Spearman coefficient equals 0.148 , with the corresponding p-value value equals 0.102 . It seems, therefore, that the position at the Bank applies marginally positively with the emotional intelligence of bank employees at $90 \%$ confidence level

$\left(6^{\text {th }}\right)$. The Spearman coefficient equals 0.142 and the corresponding value p-value equals 0.116 . At a confidence level of $90 \%$, it seems that there is no correlation of time of service and levels of emotional intelligence of employees of the banking system.

\subsection{Linear regression analysis}

A further statistical analysis was performed as a second phase of this study, on whether vocational satisfaction levels are affected by levels of emotional intelligence that bank employees of the Greek banking system noted.

At this stage of the study, a simple linear regression model was used. The equation that describes the model is $\mathrm{y}=\mathrm{a}+\mathrm{b}^{*} \mathrm{x}$, where $\mathrm{x}$ is the independent and $\mathrm{y}$ the dependent variable $\mathrm{a}$ is the constant in the model and $b$ the regression coefficient of the independent variable. Emotional intelligence was considered as the independent variable and the employees' job satisfaction as the dependent variable.

According to the results obtained from the statistical analysis and the use of the statistical package SPSS, the regression model is statistically significant with $\mathrm{F}=17.855$ and $\mathrm{p}$-value $=$ 0.000 at $90 \%$ confidence level. The levels of emotional intelligence are characterized as a statistically significant variable with $t=5,091$ and $p$-value $=0.000$ at $90 \%$ confidence level. It seems that emotional intelligence affects the job satisfaction of employees of the banking system. Therefore, as higher emotional intelligence levels are noted, the more satisfied the bank employees feel from their work. At table 7 the aggregated results of the above statistical analysis are presented.

Table 7. Aggregated results of statistical analysis through simple linear regression

\begin{tabular}{llll}
\hline & \multicolumn{3}{c}{ Job satisfaction } \\
\cline { 2 - 4 } & & $\mathrm{F}$ & $\mathrm{p}$-value \\
\hline Regression Model & Model Parameter & 17.855 & .000 \\
& .164 & $\mathrm{t}$ & $\mathrm{p}$-value \\
Emotional intelligence & .164 .226 & .000 \\
\hline
\end{tabular}

Source: Results of the Survey Questionnaire

The study was completed with the implementation of linear regression by creating six separate simple regression models posing every time as an independent one of the variables gender, age, marital status, years of service in the bank, education and position in the bank. The dependent variable for all six regression models was considered to be the emotional 
intelligence. The following table 8 presents the aggregated results of the six linear regression models.

Table 8. The aggregate results of the six linear regression models

\begin{tabular}{llll}
\hline & \multicolumn{3}{l}{ Emotional Intelligence } \\
\cline { 2 - 4 } & & Model \\
& $\mathrm{F}$ & Parameter & p-value \\
\hline Gender & 2.605 & -3.558 & .10 \\
Age & 1.338 & .162 & .25 \\
Marital Status & 1.357 & -2.276 & .246 \\
Education & 1.133 & .145 & .289 \\
Job position in the Bank & .001 & .037 & .971 \\
Years of experience in the Bank & .038 & .352 & .847 \\
\hline
\end{tabular}

Source: Results of the Survey Questionnaire

As noted in the above table, the only significant parameter that seems to affect the emotional intelligence of employees is gender with p-value 0.10 at significance level $10 \%$ (marginally accepted). All other parameters are statistically significant because the p-values are greater than the confidence level $(\mathrm{r}$-square $=0.905)$.

\section{Concluding Remarks}

The importance of emotional intelligence it dominant role in the workplace, as it is considered a key factor in creating and maintaining effective relationships in the workplace, thereby achieving higher levels of satisfaction at work.

Through the application of the current statistical analysis, the research hypotheses were investigated in this paper. Based on the statistical results, it seems that the results obtained by this empirical investigation were the expected and consistent with the theoretical background and with several of the existing empirical international studies.

The research methodology used in this paper was based on the reliability analysis based on the index Cronbach's Alpha, the study of research hypotheses through correlation analysis of corresponding parameters, the selection of statistical test of Kolmogorov-Smirnov for testing the normality of data, the use of the correlation coefficient of Spearman (rho), recommended for non-normal data and the application of simple linear regression.

Concerning the conclusions, firstly, there is a positive relationship between aspects of emotional intelligence of bank employees and the satisfaction they feel from their work. Secondly, emotional intelligence differs between the two genders. Thirdly, both the age of bank officials, as well as their marital status seems to affect the levels of their emotional intelligence. Fourthly, the educational level of bank employees has no direct relation to the levels of their emotional intelligence. Fifthly, the job position held by the employees in the bank sector seems to affect the levels of emotional intelligence. Finally, the years of service that a bank employee has do not affect the levels of emotional intelligence that he or she presents. 
In summary, it seems that the gender, age, marital status, and job position in the bank forming a part of the demographic characteristics of the sample - affect the levels of emotional intelligence of employees of the banking system. In addition, emotional intelligence seems to exert influence on the everyday life of employees and modulate the levels of professional satisfaction.

\section{References}

Abi, E., \& Jijo G. (2012). Emotional Intelligence and Job Satisfaction: A Correlational Study. Research. Journal of Commerce and Behavioral Science, 1(4), 124-141.

Abraham, R. (2000). The Role of Job Control as a Moderator of Emotional Dissonance and Emotional Intelligence-Outcome Relationships. The Journal of Psychology: Interdisciplinary and Applied, 169-184. http://dx.doi.org/10.1080/00223980009600860.

Adecemo, D.A., n.d. The Buffering effect of emotional intelligence on the adjustment of secondary school students in transition. Electronic Journal of Research in Educational Psychology, 6-3(2),79-90.

Afonso, A., Agnello, L., \&Furceri, D. (2010). Fiscal policy responsiveness, persistence, and discretion. Public Choice, 145, 503-530. http://dx.doi.org/10.1007/s11127-009-9577-x

Arvey, R.D., Bouchard, T.J. Jr., Segal, N. L., \& Abraham, L.M. (1989). Job Satisfaction: Environmental and Genetic components. Journal of Applied Psychology, 74(2), 187-192. http://dx.doi.org/10.1037/0021-9010.74.2.187

Bar-On, R. (1997). Bar-On Emotional Quotient Inventory: a measure of emotional intelligence. Toronto, ON: Multi-Health Systems.

Bhatt, R. J. (2004).A Case Study of Job Satisfaction among Bank Employees of Leading Nationalised Banks of Gujarat State. Retrieved March 13, 2014 from http://www.sbaer.uca.edu/research/ 1998/ICSB/c003.htm

Caruso, J.C., \& Cliff, N. (1997). Empirical size, coverage, and power of confidence intervals for Spearman's Rho. Ed. and Psy. Meas, 57, 637-654. http://dx.doi.org/10.1177/0013164497057004009

Choi, Daejeong, Oh, In-Sue \& Guay, Russell, P. (2011). Why Do Emotionally Intelligent People Have Positive Work Attitudes? The Mediating Role of Situational Judgment Effectiveness (December 2011). International Journal of Selection and Assessment, 19, 4.http://dx.doi.org/10.1111/j.1468-2389.2011.00564.x

Chok, N.S. (2010). Pearson's Versus Spearman's And Kendall's Correlation Coefficients For Continuous Data, MSc Thesis, University of Pittsburgh. Retrieved from http://d-scholarship.pitt.edu/8056/1/Chokns_etd2010.pdf

Dulewicz, V., \& Higgs, M. (1998). Emotional Intelligence: A review and evaluation study. $\begin{array}{llll}\text { Journal of managerial } & \text { Psychology, 15(4), }\end{array}$ http://dx.doi.org/10.1108/02683940010330993 
Edwards, J. E., \& Fisher, B. M. (2004).Evaluating employee survey programs. In J. E. Edwards, J. C. Scott, \& N. S. Raju (Eds.), The human resources program-evaluation handbook (pp. 365-386). Thousand Oaks, CA: Sage.

Goleman, D. (1998). Working with emotional intelligence. New York: Bantam Books.

Heffernan, T., O’Neill, G., Travaglione, T., \& Droulers, M. (2008). Relationship marketing: the impact of emotional intelligence and trust on bank performance. International Journal of Bank Marketing, 26(3), 183-199. http://dx.doi.org/10.1108/ 02652320810 864652

Henry, E., \& Hope, W. (2013). Principals' Emotional Intelligence and Its Impact on Adequate Yearly Progress, Journal of Educational Leadership in Action, A Publication of Lindenwood University Press.

Jawahar, D., \& Samanvitha, S. (2012). Emotional Intelligence as a Predictor of Job Satisfaction: A Study Amongst Faculty in India. The IUP Journal of Management Research, 11(1), 7-28.

Kaura, Puja, (2011). Enormity of Emotional Intelligence in India Banking Sector. Sri Krishna International Research Educational Consortium, 12(1),165-177.

Kenney, J. F., \& Keeping, E. S. (1962)."Linear Regression and Correlation." Ch. 15 in Mathematics of Statistics, Pt. 1, 3rd ed. Princeton, NJ: Van Nostrand, 252-285.

Khouly, El, Sayed, Ghoniem, Abdulazim, Ghoniem, Ghadami, Mohsen, Ghadami \& Ibrahim, Mohammed. (2010). Impact of Emotional Intelligence and Gender on Job Satisfaction Among Egyptian Government Sector Employees (November 11, 2010). Current Research Journal of Social Sciences, 3(1), 22-27.

Kluemper, D.H. (2008). Trait emotional intelligence: The impact of core-self evaluations and social desirability. Personality and Individual Differences, 44(6), 1402-1412. http://dx.doi.org/10.1016/j.paid.2007.12.008

Kraut, A. I. (1996).Organizational surveys: Tools for assessment and change. San Francisco: Jossey- Bass.

Kyriazopoulos, P.G., \& Samada, E. (2011). Research Methodology Elaboration of Dissertations. Athens: Sigxroni Ekdotiki.

Locke, E. A. (1976). The nature and causes of job satisfaction.In M. D. Dunnette (Ed.), Handbook of industrial and organizational psychology (pp. 1297-1349). Chicago: Rand McNally.

Locke, E.A., \& Latham, G.P. (2002).Building a practically useful theory of goal setting and task motivation: A 35-year odyssey. American Psychologist, 57, 705-717. http://dx.doi.org/10.1037/0003-066X.57.9.705

Lu, H., While, A.E., \& Barriball, K.L. (2007).Job satisfaction and its related factors: A questionnaire survey of hospital nurses in Mainland China. International Journal of Nursing Studies, 44, 574-588. http://dx.doi.org/10.1016/j.ijnurstu.2006.07.007

Mayer, J.D, Roberts, R. D., \& Barsade, S.G. (2008).Human Abilities: Emotional Intelligence, 
$\begin{array}{lllll}\text { Annual Review } & \text { of } & \text { Psychology, } & 59, & 507-36\end{array}$ http://dx.doi.org/10.1146/annurev.psych.59.103006.093646

Mayer, J.D., \& Salovey, P. (1997). What is emotional intelligence? In P. Salovey \& D. Sluyter (Eds.), Emotional development and emotional intelligence: Educational implications, pp. 3-31, New York: Basic Books.

Normadiah Mohd Razali, Yap Bee Wah. (2011). Power Comparisons of Shapiro-Wilk, Kolmogorov-Smirnov, Lilliefors and Anderson-Darling Tests. Journal of Statistical Modeling and Analytics, 2(1), 21-33.

Orhan, N., \& Dincer, H. (2012). The Impacts of Emotional Intelligence Competency on Job Satisfaction in the Service Sector: An Application on the Turkish Banking Sector. Asian Economic and Financial Review, 2(5), 617-634.

Rahim, S.H., \& Malik, M.I. (2010). Emotional Intelligence \& Organizational Performance: A Case Study of Banking Sector in Pakistan. International Journal of Business and Management, 5(10), 191-197.

Saari, L.M., \& Judge, T.A. (2004). Employee Attitudes and Job Satisfaction. Human Resource Management, 43(4), 395-407. http://dx.doi.org/10. 1002/hrm.20032

Salovey, P., \& Mayer, J.D. (1990).Emotional intelligence. Imagination, Cognition, and Personality, 9, 185-211. http://dx.doi.org/10.2190/DUGG-P24E-52WK-6CDG

Schutte, N.S., Malouff, J.M., Hall, L.E., Haggerty, D.J., Cooper, J.T., Golden, C. J., \& Dornheim, L (1998). Development and validation of a measure of emotional Intelligence. Personality and Individual Differences, 25, 167-177. http://dx.doi.org/10.1016/S0191-8869(98)00001-4

Tapia, M. (2001). Measuring emotional intelligence. Psychological Reports, 88(88), 353-364. http://dx.doi.org/10.2466/pr0.2001.88.2.353

Tavakol M., \& Dennick R. (2011).Making sense of Cronbach's alpha. International Journal of Medical Education, 2, 53-55. http://dx.doi.org/10.3109/ 0142159X.2011.564682

Vasiliou, D., Eriotis, N., \& Papathanasiou, Sp. (2008).Incorporating Technical Analysis into Behavioral Finance: A field experiment in the large capitalization firms of the Athens Stock Exchange. International Research Journal of Finance and Economics, 9(14), 100-112.

Webb, Kerry, S. (2011). Emotional Intelligence and Business Success (August 14, 2011).

\section{Copyright Disclaimer}

Copyright reserved by the author(s).

This article is an open-access article distributed under the terms and conditions of the CreativeCommons Attribution license (http://creativecommons.org/licenses/by/3.0/). 